apically, the distal half of the venter of the abdomen and femora rufous; tibire and tarsi mostly yellowish; tibiæ and the distal tarsal segments apically reddish brown.

Female.-Length $5.5 \mathrm{~mm}$., to tip of ovipositor $7 \mathrm{~mm}$. Similar to the male and black, except as follows: Antennæ dark brown, the third segment almost blackish; clypeus, labrum, mandibles, tegula, the apex of the abdomen dorsally, the posterior margins of the basal segments and the distal third of the abdomen ventrally (except the black ovipositor), femora and tibiæ yellowish or ferruginous; the tarsi reddish brown, the posterior darker.

Described from two males and one female.

Acantholyda ferruginea, n. sp. The sawfly described below differs so greatly from any accessible descriptions, that we have been unable to refer it to known species. It was taken on the summit of Mount Marcy in the Adirondacks, July 31, 1913.

Male.-Length $7 \mathrm{~mm}$. Head brownish black, coarsely and irregularly punctured and with anterior and posterior yellowish, ovate, orbital spots; mandibles fulvous. Antennal segments 21, the first black, with irregular, narrow, yellow annulations basally and apically, the second yellowish brown or dark brown, yellowish apically; third segment shorter than the fourth and fifth combined, the others successively shorter; the third to ninth yellowish brown, the distal segments mostly dark reddish brown. Thorax and abdomen brownish black, the segments of the latter narrowly margined with yellow, the markings on the three posterior segments angulate. Wings suffused with ferruginous, only two submarginal cells, the second cross-vein wanting; venter, coxæ and femora brownish black the tibiae and tarsi dark fulvous.

\title{
ERRATUM-Plate IX.
}

We regret that the lettering for Plate IX, in our May issue, illustrating Messrs. Brittain and Saunders' article, "Notes on the Black Apple Leaf-hopper," was omitted. The figures are arranged from top to bottom of page: Figs. 1-4 on left, Figs. 5-7 on right. The magnifications are as follows; Fig. 1 (x 43), Figs. 2-4 (x 29), Fig. 5 (x 23), Fig. 6 (x 19), Fig. 7 (x 17.5). 